\section{Combined Use of Polymyxin and Acetone to obtain Cell-free Enzymes}

NEwTON ${ }^{1}$ has shown that the bactericidal effect of the polymyxins may be explained by a disorganization of the cell-membrane, due to the combination of the antibiotic with ionized phosphate groups of phospholipid components of the membrane. These results suggest that polymyxin might be used to extract enzymes from micro-organisms. The present communication is concerned with the extraction of a nitro-reductase from Nocardia $V$.

Preliminary experiments showed that the nitroreductase activity of Nocardia $V$. was inhibited only when concentrations of polymyxin were above $100 \mu \mathrm{gm} . / \mathrm{mgm}$. dry weight of cells. When cells were treated with this antibiotic at a concentration of $50 \mu \mathrm{gm} . / \mathrm{mgm}$. dry weight, very little enzyme activity $(0-5$ per cent) was released inte the medium. On the other hand about 60 per cent of the $260 \mathrm{~m} \mu$ absorbing material of the cell was liberated.

Cells were grown in a complex medium and harvested at the end of the exponential phase by centrifugation, washed twice with 0.85 per cent saline solution and resuspended in saline at about $10 \mathrm{mgm}$. dry weight per $\mathrm{ml}$. To this suspension a polymyxin solution was added to give a final concentration of $50 \mu \mathrm{gm}$. per $\mathrm{mgm}$. dry weight of cells. The mixture was allowed to stand for 30 minutes at room temperature and centrifuged for $10 \mathrm{~min}$. at $1200 \mathrm{~g}$. The supernatant was discarded and the cells washed once in distilled water. These cells were now resuspended in a small volume of distilled water and added dropwise to 20 vol. of ice-cold acetone which was stirred vigorously until coagulation occurred. The coagulated organisms were allowed to settle and some of the clear supernatant was removed by decantation. 'The rest of the material was filtered on a Buchner funnel with moderate suction. The precipitate was washed with $100 \mathrm{ml}$. of cold acetone followed by $100 \mathrm{ml}$. of cold ether; gentle suction was maintained for a fow minutes to dry the preparation, which was transferred to a vacuum desiccator overnight. All manipulations were carried out at room temperature. Powders prepared in this way retained their original activity for several months when adequately preserved in a desiccator.

Preliminary experiments indicated that some nitroreductase enzyme can be extracted from the acetonepowdered organisms in the absence of polymyxin treatment. When acetone powders are prepared as described above, but without previous treatment with polymyxin, not more than 25 per cent of the activity can be extracted by incubation for $\mathrm{l} \mathrm{hr}$. at room temperature in distilled water, $0.16 M$ sodium chloride, $0 \cdot 2 M$ acetate buffer $p \mathbf{H} 4.5-6,0.06 M$ phosphate buffer $p \mathbf{H} \quad 5 \cdot 7-8,0 \cdot 1 M$ pyrophosphate buffer $p \mathrm{H} 6-8,0.2 M$ tris buffer $p H$ H-9 $7-2 M$ borate buffer $p \mathbf{H}$ 9-10. Longer incubations at this temperature or at $30^{\circ}$ do not increase the amount of enzyme extracted; incubation at $37^{\circ} \mathrm{C}$. leads to partial inactivation of the enzyme. The amount of the enzyme extracted was doubled when acetone powders were ground for $\mathbf{5}$ min. in a cold mortar with 75 per cent saturated ammonium sulphate solution at $p \mathrm{H} 7 \cdot 6$, left at room temperature for $30 \mathrm{~min}$., centrifuged for $20 \mathrm{~min}$. in the cold at $2000 \mathrm{~g}$, the sediment resuspended in distilled water, again centrifuged and the supernatant used for test.

Table 1 shows that pretreatment of the cells with polymyxin gives a very significant increase in the amount of enzyme extracted under some of these
Table 1. EXTRACtion OF Nitro-REdUCtase ENzYMe From ACETONE-POWDERED CELS

\begin{tabular}{|c|c|c|}
\hline & $\%$ of initial $\mathrm{e}$ & e activity \\
\hline & $\begin{array}{l}{ }^{\circ} \text { Untreated } \\
\text { cells }\end{array}$ & $\begin{array}{l}\text { Polymyxin } \\
\text { treated cells }\end{array}$ \\
\hline & 100 & 100 \\
\hline & $20-30$ & 67 \\
\hline $7 \cdot 6$ & 25 & 56 \\
\hline & 52 & $86-91$ \\
\hline
\end{tabular}

Total suspension

Distilled water extract $0.06 M$ Phosphate buffer $p \mathrm{H} 7 \cdot 6$ $75 \%$ saturated $\left(\mathrm{NH}_{4}\right)_{2} \mathrm{SO}_{4}$

conditions. Variations in the final concentration of ammonium sulphate and the temperature of extraction do not increase the degree of extraction.

Other surface-active agents such as ' $C T$ ' $A B$ ', 'Aerosol-OT', 'Tween 80', 'Tyrocidin' or 'Tyrothricin', have been tested in this connexion but they either proved to inhibit the enzyme at low concentrations ( $10 \mu \mathrm{gm}$. 'CTAB'/mgm. or $30 \mu \mathrm{gm}$. 'Aerosol'/mgm.) or to be without significant effect on the release of enzyme.

I am grateful to Drs. C. J. Shepherd and B. A. Newton for advice and interesting discussions. My thanks are due to the Ramsay Memorial Fellowships Trust which supported this research with a grant.

Medical Research Council Unit for J. R. VILlanueva

Chemical Microbiology,

Department of Biochemistry,

University of Cambridge. July 30 .

1 Newton, B. A., Bact. Re?., 20, 14 (1956).

\section{Gel Filtration as a Method for Purification of Protein-bound Peptides Exemplified by Oxytocin and Vasopressin}

WE would like to call attention to a new procedure suitable for purification of simple compounds weakly associated with high molecular weight substances. The method, which was proposed elsewhere by one of us $^{1}$, is based on separation according to molecular size achievable by means of filtration through dextran gels $^{2}$. The principle which involves three operations may be illustrated for protein-bound peptides by the following scheme :

Extract containing proteins, protein-peptide complexes and small size 1. First gel filtration

Fast moving components | Slow moving components
Proteins, protein-peptide complexes
Small size compounds

2. Splitting of complexes

3. Second gel filtration

Proteins

This mathod is, of course, possible only when the complex being studied is stable enough to survive the first gel filtration, but capable of being easily split under other conditions. Such prerequisites may appear strongly to limit the applicability of the procedure. However, this is not necessarily the case since gel filtration can be carried out rapidly under very mild conditions ${ }^{1,2}$. We have chosen purification of hog vasopressin and oxytocin as a suitable example for illustration.

Acetone-dried powder $(2.880 \mathrm{gm}$.) from posterior lobes of hog pituitaries ('PLP') was triturated for half an hour with $10 \mathrm{ml}$. of $0.2 M$ pyridine-0.05 $M$ acetic acid buffer, $p H$ 5.9. The insoluble residue was removed by centrifugation and discarded. The supernatant solution was placed on top of a column $(4 \times 60 \mathrm{~cm}$.) of 'Sephadex $G 25$ ' (water regain $2 \cdot 5$ 